\title{
Evaluation of respiratory activity of albic luvisol contaminated by zinc and nickel during spring rapeseed cultivation
}

\author{
Miljan Samardžić ${ }^{1}$ Irina V. Andreeva ${ }^{2 *} \cdot$ Zoran Galić $^{1}$ Jovica Vasin ${ }^{3}$ \\ 1 Institute of Lowland Forestry and Environment, Antona Čehova 13, 21000 Novi Sad, Serbia \\ ${ }^{2}$ Department of Ecology, Russian State Agrarian University Moscow, Timiryazevskaya st. 49, 127550 Moscow, Russia \\ ${ }^{3}$ Institute of Field and Vegetable Crops, Maksima Gorkog 30, 21000 Novi Sad, Serbia
}

\begin{abstract}
Summary: In almost all industrially developed regions of the Russian Federation, the soil is contaminated with heavy metals (HM), often in concentrations which exceed limits of safety. This contamination causes degradation of agricultural land, which underlines the importance of the complex continuous monitoring of the dynamics of on-going changes in urban ecosystems against the background of natural processes. Quantitative assessment of the environmental sustainability of the soil according to the biological indicators of its condition is of enormous importance, in particular the balance of microbial carbon in soils, which are under varying degrees of anthropogenic pressure. Experiments were carried out to determine the phytoremediation potential of the spring rapeseed plants on soil contaminated with heavy metals. The aim of the study was to assess the respiratory activity of albic luvisol at different levels of its contamination with zinc and nickel under the conditions of a growing experiment with spring rapeseed plants. The experimental data on the respiratory activity of soil artificially contaminated with zinc and nickel in the dose range of $400-800$ and $30-60 \mathrm{mg} \mathrm{kg}^{-1}$ of soil respectively, showed that microbial activity had a strong positive correlation with the presence of spring rapeseed plants in the vessels and weak correlation on the presence of toxic elements in the soil. According to the respiratory activity of albic luvisol, it was found that in the first 13 days of vegetation, cultivation of spring rapeseed plants had a positive effect on the sustainability of soil microbiocenosis to complex pollution with zinc and nickel.
\end{abstract}

Key words: albic luvisol, basal respiration, microbial biomass carbon, microbial metabolic coefficient, nickel, spring rapeseed, zinc

\section{Introduction}

In almost all industrially developed regions of the Russian Federation, soil is contaminated with heavy metals (HM), often in concentrations which exceede safe limits. This contamination causes degradation of agricultural land. Moreover, according to the Ministry of Agriculture of Russia, zinc is the most dangerous among heavy metals in terms of scale and volume of release and nickel is on the second place, which underlines the importance of the complex continuous monitoring of the dynamics of ongoing changes in agroecosystems.

Corresponding author

andreeva.borovik@gmail.com

Acknowledgements:

This paper is result of the research work financed by the Ministry of Education, Science and Technological Development of the Republic of Serbia, Project No. 451-03-68/2020-14/200197.

Cite this article:

Samardžić M., Andreeva I.V., Galić Z., Vasin T. (2020). Evaluation of respiratory activity of albic luvisol contaminated by zinc and nickel during sping rapeseed cultivation. Ratar, Port, 57 (3), 68-71.
Quantitative assessment of the environmental sustainability of the soil according to the biological indicators of its condition is of enormous importance, in particular balance of microbial carbon in soils which are experiencing varying degrees of anthropogenic pressure. Given the sensitivity of soil microbiocenosis to various impacts, determination of the status of the soil microbial community by such indicators as basal respiration (BR) and substrate-induced respiration (SIR), carbon of microbial biomass ( $\left.\mathrm{C}_{\mathrm{mic}}\right)$ and microbial metabolic coefficient $\left.\left(q^{C O}\right)_{2}\right)$ allows establishing of the features of microbiocenosis' functioning in conditions of pollution with various contaminants and to identify the degree of tolerance of anthropogenic interference, which are outlining possibilities of disturbed soil rehabilitation (Sushko et al., 2019).

Experiments were conducted in purpose of determination of the phytoremediation potential of spring rapeseed plants on soil contaminated with heavy metals (Koshkin et al., 2014, Vasenev et al., 2017). Based on the calculated HM extraction rates, biological absorption and translocation coefficients, a conclusion was drawn on the potential use of spring rapeseed for 
the rehabilitation of chemically degraded soils (Zhukova, 2017). However, the nature of the influence of spring rapeseed plants on the state of soil microbiocenosis in heavy metal-contaminated soil remained unclear. Thus, the aim of this study was to assess the respiratory activity of albic luvisol at different levels of its contamination with zinc and nickel under the conditions of a growing experiment with spring rapeseed plants.

\section{Material and Methods}

As a foundation of the experiment, an arable layer of albic luvisol (according to WRB classification) from the territory of the Field experimental station of the Russian State Agrarian University - Moscow Timiryazev Agricultural Academy was used, with the following agrochemical characteristics: $\mathrm{pH}_{\mathrm{KCl}}-7.13$, humus (Tyurin method) - $2.36 \%$, hydrolytic acidity $0.41 \mathrm{mg}$-eq $100 \mathrm{~g}^{-1}, \mathrm{~N}_{\text {total }}-0.12 \%, \mathrm{P}_{2} \mathrm{O}_{5 \text { mobil. }}-367.78 \mathrm{mg} \mathrm{kg}^{-1}, \mathrm{~K}_{2} \mathrm{O}$; $240.5 \mathrm{mg} \mathrm{kg}^{-1}, \mathrm{Zn}$ and $\mathrm{Ni}$ (gross content) - 41.4 and 13.3 $\mathrm{mg} \mathrm{kg} \mathrm{kg}^{-1}$, respectively. Determination of agrochemical indicators of the soil was carried out in accordance with generally accepted methods. Background macrofertilizers were applied in the form of NPK fertiliser with the ratio of basic nutrients 16:16:16. Soil contamination was simulated by complex application of zinc $(\mathrm{Zn})$ and Nickel $(\mathrm{Ni})$ in the form of solutions of $\mathrm{ZnSO}_{4} \cdot 7 \mathrm{H}_{2} \mathrm{O}$ and $\mathrm{NiSO}_{4} \cdot 7 \mathrm{H}_{2} \mathrm{O}$ salts. The total indicator of soil contamination with the combined application of Zinc and Nickel in doses of 400 and 30 $\mathrm{mg} / \mathrm{kg}$, respectively, was 9.4 (permissible level of contamination in according to the environmental legislation of the Russian Federation), and in doses of 800 and $60 \mathrm{mg} / \mathrm{kg}-19.8$ (moderately dangerous level of pollution in according to the environmental legislation of the Russian Federation).

The experiment was conducted on vessels filled with 6 kilograms of contaminated soil with planted rapeseed variety Petranova (seven plants per vessel) and blank vessels with soil without plants. The experiment was conducted in a fourfold repetition. In purpose of assessment of respiratory activity dynamics of albic luvisol in the first and second half of the growing season (on the 13th and 66th day after sowing rapeseed), soil samples were taken from each vessel, dried for 1 to 2 days on air at room temperature, and sieved (mesh diameter $1 \mathrm{~mm}$ ). The samples were weighed to $2 \mathrm{~g}$, placed in $15 \mathrm{ml}$ vials and moistened with distilled water to $60 \%$ of the total moisture capacity.

Substrate-induced respiration of the soil was assessed by the rate of initial maximum respiration of microorganisms after $0.2 \mathrm{ml} \mathrm{7.5 \%} \mathrm{solution} \mathrm{of} \mathrm{glucose}$ was induced to the soil sample. Soil samples with glucose were hermetically closed in vial and incubated for 3 hours on $22^{\circ} \mathrm{C}$. After incubation, air sample was taken from the vial and analysed on gas chromatograph. Speed of SIR was expressed in $\mu \mathrm{COO}_{2} \mathrm{~g}^{-1}$ of the soil $\mathrm{h}^{-1}$.
Basal respiration was measured by the rate of $\mathrm{CO}_{2}$ emission from the soil sample after 24 hours of incubation on the temperature of $22^{\circ} \mathrm{C}$. The methodology was the same as in case of SIR determination, the only difference was that distilled water was used instead of the glucose solution in the same quantity. Speed of BR was expressed in $\mu \mathrm{l} \mathrm{CO} 2 \mathrm{~g}^{-1}$ of the soil $\mathrm{h}^{-1}$. Measurements of SIR and BR were performed in fivefold repetition, and received results were calculated on dry soil and expressed as an average \pm standard deviation (Table 1).

Carbon of microbial biomass was calculated by formula:

$\mathrm{C}_{\text {mic }}\left(\mu \mathrm{g} \mathrm{CO}_{2} \mathrm{~g}^{-1}\right.$ of the soil $)=\mathrm{SIR}\left(\mu \mathrm{CO}_{2} \mathrm{~g}^{-1}\right.$ of the soil $\left.\mathrm{h}^{-1}\right) \times 40.04+0.37$

Microbial metabolic coefficient $\mathrm{qCO}_{2}$ was calculated as ratio between basal respiration rate and carbon of microbial biomass:

$$
\mathrm{BR} / \mathrm{C}_{\text {mic }}=q \mathrm{CO}_{2}\left(\mu \mathrm{g} \mathrm{CO}_{2}-\mathrm{C} \mathrm{mg}^{-1} \mathrm{C}_{\text {mic }} \mathrm{h}^{-1}\right) .
$$

Statistical data processing was performed using the tools of basic statistics of the Microsoft Excel.

\section{Results and discussion}

Basal respiration of soil microorganisms characterizes the emission of $\mathrm{CO}_{2}$ from the soil (Gavrilenko et al., 2011; Ananyeva et al., 2008; Creamer et al., 2014). Intensity of BR is closely related to the total biological activity of the soil and can act as an indicator of its pollution (Vasenev et al., 2013; Creamer et al., 2014). An increase in BR intensity is generally an evidence of deterioration of the conditions on which soil microorganisms can live (Anderson \& Domsch 1978; Koshkin et al., 2014; Sarzhanov et al., 2015). During experiment, it was found that during the first selection in variants with plants, there were no differences in the quantity of the BR and in general they were $1.3-2.6$ times lower than the same values in the non-plant variants. Apparently, at the initial stage of the experiment, the presence of plants in the vessels smoothed out the negative impact of the introduced toxicants on the soil microflora.

In contrast to BR, the value of substrate-induced respiration, which characterizes the potential activity of the soil microbial community, did not shown any correlation with the presence of heavy metals in the studied dose range during the first selection, but it significantly depended on the "presence of plants" factor: in the variants with plants, the value of SIR was $1.8-2.6$ times higher than in similar variants without plants. This shows that high microbial potential indicates a greater ability of the system to maintain balance under the influence of external influences. In the second half of the growing season in all variants, the SIR values increased significantly - by 2-8 times 
Table 1. Impact of spring rapeseed plants and different levels of complex contamination of albic luvisol with Zinc and Nickel on the dynamics of the carbon of microbial biomass content, basal respiration, substrate induced respiration and microbial metabolic coefficient

\begin{tabular}{|c|c|c|c|c|c|}
\hline & Variants & BR & SIR & $\mathrm{C}_{\text {Inic }}$ & $q \mathrm{CO}_{2}$ \\
\hline \multicolumn{6}{|c|}{ The first selection (the start of the vegetation, first ten days) } \\
\hline \multirow{3}{*}{$\begin{array}{l}\text { Without } \\
\text { rapeseed } \\
\text { plants }\end{array}$} & Control & $0.71 \pm 0.15$ & $3.20 \pm 0.88$ & $129 \pm 25$ & $5.91 \pm 1.95$ \\
\hline & Control $+\mathrm{Zn} 400+\mathrm{Ni} 30$ & $0.77 \pm 0.14$ & $3.22 \pm 0.32$ & $129 \pm 13$ & $6.18 \pm 1.55$ \\
\hline & Control + Zn $800+\mathrm{Ni} 60$ & $0.41 \pm 0.06$ & $2.30 \pm 0.53$ & $92 \pm 11$ & $5.55 \pm 1.09$ \\
\hline \multirow{3}{*}{$\begin{array}{l}\text { With } \\
\text { rapeseed } \\
\text { plants }\end{array}$} & Control & $0.38 \pm 0.09$ & $5.64 \pm 1.36$ & $211 \pm 80$ & $1.91 \pm 0.71$ \\
\hline & Control $+\mathrm{Zn} 400+\mathrm{Ni} 30$ & $0.30 \pm 0.06$ & $7.93 \pm 0.65$ & $317 \pm 26$ & $0.93 \pm 0.24$ \\
\hline & Control + Zn $800+\mathrm{Ni} 60$ & $0.31 \pm 0.05$ & $5.96 \pm 0.60$ & $239 \pm 25$ & $1.30 \pm 0.19$ \\
\hline \multicolumn{6}{|c|}{ The second selection (middle of the vegetation) } \\
\hline \multirow{3}{*}{$\begin{array}{l}\text { Without } \\
\text { rapeseed } \\
\text { plants }\end{array}$} & Control & $1.19 \pm 0.06$ & $17.78 \pm 2.91$ & $712 \pm 117$ & $2.12 \pm 0.25$ \\
\hline & Control $+Z \mathrm{n} 400+\mathrm{Ni} 30$ & $0.87 \pm 0.07$ & $14.40 \pm 1.75$ & $577 \pm 70$ & $1.54 \pm 0.32$ \\
\hline & Control + Zn $800+\mathrm{Ni} 60$ & $0.77 \pm 0.09$ & $18.21 \pm 3.28$ & $730 \pm 59$ & $1.10 \pm 0.10$ \\
\hline \multirow{3}{*}{$\begin{array}{l}\text { With } \\
\text { rapeseed } \\
\text { plants }\end{array}$} & Control & $1.34 \pm 0.12$ & $20.19 \pm 3.93$ & $809 \pm 157$ & $1.31 \pm 0.18$ \\
\hline & Control $+\mathrm{Zn} 400+\mathrm{Ni} 30$ & $1.20 \pm 0.06$ & $15.48 \pm 3.60$ & $620 \pm 63$ & $1.89 \pm 0.47$ \\
\hline & Control + Zn $800+\mathrm{Ni} 60$ & $0.96 \pm 0.06$ & $15.83 \pm 3.11$ & $634 \pm 124$ & $2.62 \pm 0.60$ \\
\hline
\end{tabular}

Units used for measurement: Carbon of microbial biomass content $\left(\mathrm{C}_{\text {mic }}, \mu \mathrm{g} \mathrm{CO}_{2} \mathrm{~g}^{-1}\right.$ of the soil), basal respiration $\left(\mathrm{BR}, \mu \mathrm{l} \mathrm{CO}_{2} \mathrm{~g}^{-1}\right.$ of the soil h-1), substrate induced respiration ( $\mathrm{SIR}, \mu \mathrm{l} \mathrm{CO} 2 \mathrm{~g}^{-1}$ of the soil h${ }^{-1}$ ) and microbial metabolic coefficient $\left(q \mathrm{CO}_{2}, \mu \mathrm{CO}_{2}-\mathrm{C} \mathrm{mg}^{-1} \mathrm{C}_{\text {mic }} \mathrm{h}^{-1}\right)$

compared to the same data of the first selection, and they were not significantly influenced by any of the studied factors.

Carbon of microbial biomass represents a significant ecological and physiological indicator that reflects the state of soil organic carbon (Sushko et al., 2019, Sarzhanov et al., 2015, Alvarez et al., 2001). Data obtained during the first selection showed that the $C_{\text {mic }}$ in non-plant variants was $1.6-2.6$ times lower than in the same variants with plants. Checking the significance of differences in the mean between the studied factors using the Kruskal-Wallis criterion showed that the differences between variants with and without plants were significant and that there were no significant differences in the "dose of Zinc and Nickel" factor.

By the time of the second selection, there were no statistically significant differences between the experiment variants for any factor, according to the Tukey criterion. It is necessary to note a significant increase in values of $\mathrm{C}_{\text {mic }}$ in all variants in the second half of the growing season compared to the data obtained during the first selection, which may be result of the increase in the amount of mineralized carbon in the soil. The highest value of $\mathrm{C}_{\text {mic }}$ was recorded in the control variant with plants without toxicants and amounted to $809 \mu \mathrm{g} \mathrm{CO} 2 \mathrm{~g}^{-1}$ of the soil.

The specific respiration rate of microbial biomass $q \mathrm{CO}_{2}$, which is also called the microbial stress index, reflects the ecophysiological status of the soil microbial community and is an important indicator of the efficiency of substrate use (Vasenev et al., 2013). When the soil system is stable, this indicator is usually reduced, while anthropogenic impacts lead to an increase in $q \mathrm{CO}_{2}$ values. According to obtained data, in plants in the initial period of the growing season and in all variants in the second half of the growing season regardless of the level of any toxicants, $9 \mathrm{CO}_{2}$ values were in the range from 0.93 to $2.62 \mu \mathrm{g} \mathrm{CO} 2-\mathrm{C} \mathrm{mg}^{-1} \mathrm{C}$ mic $h^{-1}$. At the first section, in non-plant variants, including the control one, at the furst selection, the values of this indicator were on average 5-6 times higher than the values obtained in other variants, which indicates a disbalance in soil microflora functions. The calculated values of the microbial respiration coefficient $(\mathrm{QR})$, the ratio of the absolute value of BR to SIR (which indicates the stability of the soil microbiocenosis) (Zhukova, 2017), confirmed the weak degree of its disturbance in the variants without plants at the first selection $(0.18-0.24)$, while in other variants the degree of disturbance of stability was absent $(\mathrm{QR}<0.1)$.

\section{Conclusion}

The experimental data on the respiratory activity of the artificially contaminated soil with zinc and nickel (the dose range of $400-800$ and $30-60 \mathrm{mg} \mathrm{kg}^{-1}$ of soil respectively), showed that statistically significant changes in the functioning of the microbial community were mainly caused by the phytogenic factor (the presence of spring rapeseed plants in the vessels) and weakly depended on the presence of toxic elements in 
the soil. Comparison of the soil respiratory activity data obtained between non- plant variants and plant variants after the first 13 days of the experiment (lower BR values and high SIR, increased carbon content of microbial biomass and low $9 \mathrm{CO}_{2}$ values) indicates a significant contribution of the plant variants to increased soil microbiocenosis stability to the studied toxic elements. In the second half of the growing season of rapeseed plants, differences between variants were smoothed out, probably due to microbial community's overcoming and adapting to stress. Further research is needed to confirm the identified trends, in order to develop practical recommendations for the remediation of degraded soils.

\section{References}

Sushko S.V., Ananyeva N.D., Ivashchenko K.V., Kudeyarov V.N. (2019). Soil $\mathrm{CO}_{2}$ emission, microbial biomass, and basal respiration of chemozems under different land uses. Eumasian Soil Sicence 52 (9), 1091-1100.

Koshkin E. I., Andreeva I.V, Belopukhov S.L. (2014). Ocenka fitoremediacionnogo potenciala sortov yarovogo rapsa (Brassica napus L.) v usloviyah zagryaznennoy tyazhyolymi metallami demovo -podzolistoy pochvy [Кошкин, Е.И., Андреева И.В., Белопухов C. $\Lambda$ (2014). Оценка фиторемедиационного потенциала сортов ярового рапса (Brassica napus L.) в условиях загрязненной тяжелыми метамами Аерново-подзолистой почвы. Агрохимия. 8, 79-87.] Agrobimiza 8, 79-87.

Anderson J. P. E. and K. H. Domsch (1978). A physiological method for the quantitative measurement of microbial biomass in soils. Soil Biol. Biochem. 10 (3), 215-221

Vasenev I., Andreeva I., Koshkin E., Samardžić M. (2017). Possibilities of rapeseed cultivation as bioenergetic crop under conditions of chenically degraded soils in Russia. SGEM2017 Vienna GREEN Conference Proceedings, ISBN 978-619-7408-28-7 / ISSN 1314-2704, 27. Vol. 17, Issue 43, 725-732 pp; DOI: $10.5593 / \mathrm{sgem} 2017 \mathrm{H} / 43$ / S29.091

Vasenev V.I., Anan'eva N.D., Ivashchenko K.V. (2013). The effect of pollutants (heavy metals and diesel fuel) on the respiratory activity of constructozems (artificial soils). Russian joumal of Ecology 44 (6), 475-483.

Gavrilenko, E.G., E.A. Susyan, N.D. Anan'eva and O.A. Makarov (2011). Spatial variability in the carbon of microbial biomass and microbial respiration in soils of the south of Moscow Oblast. Eurasian Soil Science 44, 1125-1138.

Sarzhanov D. A. , V. I. Vasenev, Yu. L. Sotnikova, A. Tembo, I. I. Vasenev, R. Valentini (2015). Short-term dynamics and spatial heterogeneity of $\mathrm{CO}_{2}$ emission from the soils of natural and urban ecosystems in the Central Chernozemic Region. Eurasian Soil Soi. $48,416-424$.

Alvarez R., C. R. Alvarez, G. Lorenzo. Carbon dioxide fluxes following tillage from a Mollisol in the Argentine Rolling Pampa. Eur. J. Soil Biol. 37, 161-166 (2001).

Ananyeva N. D. , E. A. Susyan, O. V. Chemova, S. Wirth. (2008). Microbial respiration activities of soils from different climatic regions of European Russia . Eur. J. Soil Biol 44 (2), 147-157.

Creamer R. E. , R. P. O. Schulte, D. Stone, A. Gal, P. H. Krogh, G. Lo Papa, P. J. Murray, G. Pérès, B. Foerster, M. Rutgers, J. P. Sousa, A (2014). Winding. Measuring basal soil respiration across Europe: Do incubation temperature and incubation period matter? Ecol. Indic. 36, 409-418.

Zhukova A.D. (2017). Ocenka ekologicheskogo sostoyaniya pocbs na territorii impaktnogo vliyaniya proizvodstva fosfosoderzbashchib mineral'nyb udobreniy (na primere OAO "Voskresenskie mineral'nye udobreniyac) dis. kand. biol. nauk: 03.0208/ A.D. Zhukova, Moskva, 169. [Жукова A.D. (2017) Оценка экологического состояния почв на территории импактного вАияния производства фосффорсодержащих минеральных удобрений (на примере ОАО (Воскресенские минеральные удобрения)). Аис. ... канА, биол. наук 03.02.08 / А.А. Жукова. Москва, 169.]

\section{Ocena aktivnosti disanja u albičnom luvisolu kontaminiranom sa Zn i Ni tokom gajenja jare uljane repice}

\section{Miljan Samardžić · Irina V. Andreeva · Zoran Galić · Jovica Vasin}

Sažetak: U skoro svim industrijski razvijenim regionima Ruske Federacije zemljište je kontaminirano teškim metalima, često u koncentracijama koje prelaze sigurne granice. Ova kontaminacija izaziva degradaciju poljoprivrednog zemljišta, što ističe važnost kompleksnog kontinuiranog praćenja dinamike neprekidnih promena u urbanim ekosisemima u odnosu na prirodne procese. Kvantitativna procena ekološke održivosti zemljišta prema biološkim pokazateljima njegovog stanja je od ogromnog značaja, posebno ravnoteža mikrobnog ugljenika u zemljištima koja imaju različit stepen antropogenog pritiska. Eksperimenti su sprovedeni u svrhu odredivanja fitoremedijacionog potencijala biljaka uljane repice na zemljištu kontaminiranom teškim metalima. Cilj istraživanja bila je procena respiratorne aktivnosti albičkog luvisola, pri različitim nivoima kontaminacije cinkom i niklom u uslovima vegetativnog eksperimenta sa biljkama uljane repice. Eksperimentalni podaci o respiratornoj aktivnosti tla veštački kontaminiranog cinkom i niklom u rasponu doza od 400-800, odnosno 30-60 $\mathrm{mg} \mathrm{kg}^{-1}$ zemlijišta, pokazali su da mikrobna aktivnost ima jaku pozitivnu korelaciju sa prisustvom biljaka uljane repice u posudama i slabu u odnosu na prisustvo toksičnih elemenata u tlu. Prema respiratornoj aktivnosti albičkog luvisola, utvrđeno je da je u prvih 13 dana vegetacije gajenje jarih biljaka uljane repice pozitivno uticalo na održivost mikrobiocenoze zemljišta u uslovima kompleksnog zagađenja cinkom i niklom.

Ključne reči: jara uljana repica, cink, nikl, albični luvisol, disanje zemljišta, ugljenik biomase mikroorganizama, mikrobiološki metabolički koeficijent

This article is distributed under the terms of the Creative Commons Attribution 4.0 International License (http:/creativecommons.org/licenses/bv/4.0). which permits unrestricted use, distribution and reproduction in any medium, provided you give appropriate credit to the original author(s) and the source, provide a link to the Creative Commons license, and indicate if changes were made 